\title{
KEBEBASAN BERTINDAK ADMINISTRASI NEGARA DALAM NEGARA HUKUM MODERN
}

\author{
Oleh: I Dewa Ayu Widyani \\ dewaayua@ymail.com \\ Universitas Kristen Indonesia, Jakarta, Indonesia
}

\begin{abstract}
In a modern law state, freedom of the state administration or government to act that is not creating abuse of power, it therefore should be limited. Unagainst the existing law system, enacted in urgent situation for public purposes and implemented in proper government ethical basis.
\end{abstract}

Keywords: modern law state; administration; government, abuse of power.

\section{Pendahuluan}

Dalam perkembangan zaman, aliran ligisme yang menganggap Hukum adalah Undang-undang sudah tidak dapat dipertahankan lagi dalam suatu negara Hukum Modern yang mempunyai tujuan tidak hanya menjaga keamanan tetapi juga menyelenggarakan kesejahteraan umum oleh Pemerintah (bestuurs zorg), disebut juga sebagai Negara Kesejahteraan atau Welfare State.

Indonesia sebagai Negara Hukum Modern telah mengatur tujuan ini dalam Pembukaan UUD 1945 alinea ke empat yaitu...untuk mewujudkan kesejahteraan umum....serta dengan mewujudkan keadilan sosial bagi seluruh rakyat Indonesia. Konsekwensi dari ketentuan ini mengharuskan Pemerintah sebagai administrasi Negara proaktif mencampuri bidang kehidupan masyarakat dengan memberikan pelayanan umum atau mengusahakan kesejahteraan bagi masyarakat disamping memberikan perlindungan. "Pemerintah tidak boleh menolak untuk memberikan pelayanan kepada masyarakat dengan alasan tidak ada peraturan perundang-undanganyang mengaturnya". Mengingat tidak semuapermasalahan yang timbul dalam masyarakat terakomodir dalam undang-undang atau karena sifat undang-undang yang tidak dapat dibuat terlalu rinci, jika Pemerintah atau administrasi negara harus selalu terikat pada hukum tertulis atau undang-undang saja, sulit baginya untuk dapat segera menanggulangi masalah-masalah yang timbul dalam masyarakat. Untuk itu Pemerintah atau administrasi negara diberikan kebebasan bertindakdi luar undang-undang guna menyelesaikan masalahmasalah konkrit. Permasalahannya adalah kebebasan bertindak yang bagaimana dapat diberikan kepada Pemerintah atau administrasi negara, apakah kebebasan bertindak tersebut tidak melanggar azas legalitas dalam suatu negara hukum, atau bahkan cenderung dapat menimbulkan penyalahgunaan wewenang oleh Pemerintah (de tournement de pouvoir).

\section{Pembahasan \\ Kebebasan Bertindak Administrasi}

Dalam teori Hukum Administrasi Negaradikenal 3 (tiga) jenis kemerdekaan bertindak

\section{Freies Ermessen}

Menurut Diana Halim Koentjoro (2004;41) Freies Ermessen adalah kemerdekaan bertindak administrasi negara atau Pemerintah (eksekutif) untuk menyelesaikan masalah yang timbul dalam keadaan kegentingan yang memaksa, dimana Peraturan Penyelesaian untuk masalah itu belum ada.

Lebih lanjut Marcus Lukman (1996:205) 
menyebutkan Freies Ermcssen (diskresionare)diartikan sebagai salah satu sarana yang memberikan ruang bergerak bagi pejabat atau badan-badan Administrasi Negara untuk melakukan tindakan tanpa harus terikat sepenuhnya pada undang-undang.Definisi senadajuga diberikan oleh Nata Saputra (1988:15) yaitu suatu kebebasan yang diberikan kepada alat Administrasi, yaitu kebebasan yang pada azasnya memperkenankan alat Administrasi Negara mengutamakan keefektifan tercapainya suatu tujuan (=doelmatigheid) dari pada berpegang teguh kepada ketentuan Hukum; atau kewenangan yang sah untuk turut campur dalam kegiatan sosial guna melaksanakan tugas-tugas menyelenggarakan kepentingan umum.

Pengertian-pengertian ini menunjukan bahwa kebebasan Pemerintah atau Administrasi Negara diperlukan sebagai konsekwensi campur tangan Pemerintah dalam kehidupan masyarakat agar dapat bertindak cepat untuk mengatasi kejadiankejadian yang tidak dapat diperkirakan sebelumnya, karena belum ada undang-undang yang mengatur tentang penyelesaiannya secara konkrit, sementara perlu penyelesaian segera misalnya menghadapi bencana alam atau wabah penyakit menular, maka Pemerintah harus segera mengambil tindakan yang menguntungkan bagi negara dan rakyat, tindakan mana timbul atas inisiatif sendiri.

\section{Delegasi Perundang-Undangan (delegasi van wetgeving)}

Administrasi Negara diberikan kekuasaan untuk membuat peraturan organik pada undang-undang. Oleh karena pembuat undang-undang di pusat tidak dapat mengakomodir secara rinci semua kebutuhan atau permasalahan yang timbul di daerah di seluruh wilayah Indonesia, sehingga kepada Pemerintah atau Administrasi Negara diberikan tugas untuk membuat peraturan-peraturan Pemerintah berdasarkandelegasi perundang-undangan untuk menjalankan undangundang sebagai mana mestinya (Pasal 5 ayat 2 UUD 1945).

Hal ini dilakukan oleh karena sifat suatu undangundang dimana pembuat undang-undang Pusat hanya membuat peraturan secara garis besarnya saja dan kepada administrasi Negara atau Pemerintahlah yang kemudian menyelesaikan peraturan-peraturan yang dibuat badan legislatif dengan keadaan konkrit di wilayah daerah masing-masing.

Muchsan (1981:27-28) adanya delegasi perundangundangan maksudnya aparat Pemerintah diberi kekuasaan untuk mengatur sendiri, yang sebenarnya kekuasaan itu merupakan kekuasaan aparat yang lebih tinggi tingkatannya, misalnya dalam menggali sumber-sumber keuangan daerah. Pemerintah Daerah Bebas untuk mengelolanya asalkan sumber-sumber itu merupakan sumber- sumber yang sah.

\section{Droit Function}

Droit Function adalah kemerdekaan administrasi negara atau Pemerintah untuk menyelesaikan suatu peristiwa yang konkrit dalam masyarakat akan tetapi tidak berdasarkan suatu delegasi yang tegas. Seperti halnya kebebasan Pemerintah untuk menentukan obyek-obyek tertentu yang dapat didirikan, sebagaimana ketentuan Pasal 1 ayat $1 \mathrm{HO}$ (Hinderordonantic / UU Gangguan) yang menyebutkan obyek-obyek mana yang tidak boleh didirikan tanpa izin dari Pemerintah. ...... "Ketentuan ini berakhir dengan kata-kata" dan semua bangunan-bangunan lain yang dapat menimbulkan bahaya, kerugian dan gangguan. Dengan demikian kepada Administrasi Negara diberikan kebebasan untuk menentukan apakah suatu obyek yang akan didirikan termasuk salah satu ketentuan tersebut sehingga dianggap perlu mendapatkan izin atau sama sekali tidak memerlukan izin dari Pemerintah. Hal ini tergantung kepada pendapat dan kejujuran dari Administrasi Negara yang berwenang mengeluarkan izin tersebut.

Kebebasan bertindak Pemerintah atau Administrasi Negara baik dalam melakukan tindakan biasa maupun tindakan hukum, dan ketika hal ini diwujudkan dalam instrumen yuridis yang tertulis, jadilah ia sebagai peraturan kebijaksanaan, Ridwan HR (2002:134) menyebutkan antara lain garis-garis kebijaksanaankebijaksanaan, peraturan-peraturan, petunjukpetunjuk, surat edaran, resolusi-resolusi, instruksi, nota kebijaksanaan, peraturan menteri, keputusankeputusan pengumuman-pengumuman. 


\section{Batas Kebebasan Bertindak Administrasi Negara}

Meskipun Pemerintah atau Administrasi Negara diberikan kebebasan untuk dapat bertindak atas inisiatif sendiri dalam menyelesaikan permasalahan yang timbul dalam masyarakat namun tetap harus mengingat beberapa hal. Menurut Muchsan (1981:28):

- Tidak boleh bertentangan dengan sistem hukum yang berlaku (Kaidah Hukum Positif)

- Hanya ditujukan demi kepentingan umum.

Hal ini sejalan dengan yang dikemukakan Diana Halim Kuntjoro (2004:44) kemerdekaan Administrasi Negara harus tetap mengingat azas legalitas (setiap tindakan pejabat administrasi negara harus ada dasar hukumnya atau peraturan dasar yang melandasi serta mengingat kepentingan umum. Kuntjoro Purbo Pranoto (1985:39) kepentingan umum dapat dirinci :

- Memelihara kepentingan umum yang khusus mengenai kepentingan negara. Contohnya tugas pertahanan dan keamanan.

- Memelihara kepentingan umum dalam arti memelihara kepentingan bersama warga negara, contoh: Persediaan sandang pangan, perumahan dan kesejahteraan sosial.

- Memelihara kepentingan bersama yang tidak seluruhnya dapat dilakukan oleh warga negaradalam bentuk bantuan negara. Adakalanya memelihara seluruh kepentingan perseorangan, contoh pemeliharaan fakir miskin dan anak terlantar.

Safri Nugraha (2007:39) kebebasan seorang Pejabat Administrasi Negara mengambil keputusan berdasarkan pendapatnya sendiri, asalkan tidak melanggar asas yuridikitas (rechmatigeheid) yaitu setiap tindakan pejabat administrasi negara tidak boleh melanggar hukum secara umum (harus sesuai dengan rasa keadilan dan kepatutan), dan azas legalitas (wet matigeheid).

Disamping itu, Sjachran Basah (195:151) bahwa kebebasan tersebut harus dapat dipertanggung jawabkan secara moral kepada Tuhan Yang Maha Esa, menjunjung tinggi harkat dan martabat manusia serta nilai-nilai kebenaran dan keadilan, mengutamakan persatuan dan kesatuan demi kepentingan bersama. Dengan demikian dalam setiap tindakan administrasi negara dibatasi oleh adanya ketaat-azasan ketentuan, perundang-undangan berdasarkan azas taat azas, yaitu peraturan yang tingkat derajatnya lebih rendah tidak boleh bertentangan, dengan peraturan yang tingkat derajatnya lebih tinggi sementara peraturan yang dibuat atau sikap tindak administrasi negara (baik aktif maupun pasif tidak boleh melanggar hak dan kewajiban azasi warga).

Karena kebebasan yang tidak terbatas dapat menimbulkan de tournament de pouvoir (penyalahgunaan wewenang) penggunaannya harus dengan alasan-alasan tertentu. Bachsan Mustafa (1979:111-112) menyebutkan antara lain :

- Ada alasan penting atau alasan yang dapat dibenarkan yang menjadi latar belakang perbuatan administrasi negara.

- Perbuatan itu masih ada dalam ruang lingkup tugas yang diberikan kepadanya oleh undang-undang.

- Pejabat administrasi negara yang bersangkutan mempertanggung jawabkan perbuatannya.

Sjachran Basah (1995:68) mengemukakan kebebasan administrasi negara harus mengandung unsur-unsur:

- Ditujukan untuk menjalankan tugas-tugas servis publik

- Merupakan sikap tindak yang aktif dari administrasi negara

- Sikap tindak itu dimungkinkan oleh Hukum

- Sikap tindak itu diambil atas inisiatif sendiri

- Sikap tindak itu dimaksudkan untuk menyelesaikan persoalan-persoalan penting yang timbul secara tiba-tiba

- Sikap tindak itu dapat dipertanggungjawabkan baik secara moral kepada Tuhan yang Maha Esa maupun secara hukum.

Meskipun kebebasan bertindak disebabkan karena UU tidak mengatur secara rinci setiap permasalahan yang timbul dalam masyarakat namun dalam penerapannya kebebasan bertindak tersebut harus tetap memperhatikan azas-azas pemerintahan yang layak (baik) yang meliputi azas perlakuan yang sama menurut hukum, azas kepatutan dan kewajaran, azas keseimbangan, azas pemenuhan kebutuhan dan harapan, serta azas kelayakan mempertimbangkan 
segala sesuatu yang relevan dengan kepentingan publik dan warga masyarakat.

\section{Kesimpulan dan Saran}

Dari uraian di atas dapat disimpulkan bahwa dalam suatu negara hukum modern yang bertujuan bukan hanya menjaga keamanan tetapi juga menyelenggarakan kesejahteraan umum (bestuurszorg), Administrasi Negara diberikan kebebasan bertindak atas inisiatif sendiri di luar Undang-undang untuk menyelesaikan permasalahan-permasalahan yang timbul di masyarakat mengingat undang-undang tidak mengatur permasalahan tersebut secara rinci.

Kebebasan administrasi negara dapat meliputi Freies Ermessen (azas diskresi). Delegasi perundangundangan maupun melalui delegasi yang tidak tegas (Droit Function).

Untuk menghindari penyalahgunaan wewenang yang dilakukan oleh Pemerintah (de tour nement de pouvoir). Dalam mempergunakan kebebasan bertindak harus berdasarkan alasan-alasan tertentu yaitu :

- Alasan penting atau alasan yang dapat dibenarkan

- Perbuatan itu masih ada dalam ruang lingkup tugas yang diberikan kepadanya oleh undang-undang

- Dapat mempertanggung-jawabkan perbuatannya.

Dengan demikian batasan-batasan kebebasan administrasi negara dalam bertindak adalah tidak boleh bertentangan dengan sistem hukum yang berlaku (Kaidah Hukum Positif), dilakukan dalam keadaan mendesak untuk kepentingan umum.

Kebebasan bertindak ini dilakukan akibat keterbatasan ketentuan hukum tertulis (UU) maka di dalam penerapannya harus tetap memperhatikan azas-azas pemerintahan yang baik/layak seperti; azas perlakuan yang sama menurut hukum, azas kepatutan dan kewajaran, azas keseimbangan, azas pemenuhan kebutuhan dan harapan, azas kelayakan mempertimbangkan segala sesuatu yang relevan dengan kepentingan publik dan warga masyarakat.

\section{DAFTAR PUSTAKA}

Diana Halim Koentjoro, Hukum Administrasi Negara, Ghalia Indonesia, 2004.

Indro Harto, Usaha Memahami Undang-undang Tentang Peradilan Tata Usaha Negara, Pustaka Sinar Harapan, Jakarta, 1993.

Kuntjoro Purbo Pranoto, Beberapa Catatan Hukum Tata Pemerintahan dan Pendidikan Administrasi Negara, Alumni Bandung, 1975.

Markus Lukman, Eksistensi Peraturan Kebijaksanaan dalam Bidang Perencanaan dan Pelaksanaan Rencana Pembanguan Di Daerah Serta Dampaknya Terhadap Pembangunan Materi Hukum Tertulis Nasional, Desertasi, Universitas Pajajaran, Bandung, 1996.

Muchsan, Beberapa Catatan Tentang Hukum Administrasi Negara dan Peradilan Administrasi di Indonesia, Liberty, Yogyakarta, 1981.

Nata Saputra, Hukum Administrasi Negara, Rajawali, Jakarta, 1988.

Philipus M. Hardjon, Pengantar Hukum Administrasi Negara, Gajahmada University Press, Yogyakarta, 1993.

Safri Nugraha, Hukum Administrasi Negara, Fakultas Hukum Universitas Indonesia, 2005.

Syachran Basah, Eksistensi dan Tolak Ukur Badan Peradilan Administrasi Negara, Alumni, Bandung, 1985. 